J. Japan. Soc. Hort. Sci. 56(3) : 300-305. 1987.

\title{
Protein Analysis on Pistils and Pollens of Almonds with Special Reference to Sf, a Self-fertile Gene ${ }^{1}$
}

\author{
Kensuke Yamashita \\ Department of Agronomy, Miyazaki University, \\ Miyazaki $889-21$ \\ Thierry Gaude and Christian Dumas \\ Départment de Biologie Végétale, Universitè Claude Bernard \\ Lyon 1, Villeurbanne, France \\ Charles Grasselly and Patrice Crossa-Raynaud \\ I. N.R. A., Station de Recherches Fruitières Méditerranéennes, \\ Montfavet, France
}

\begin{abstract}
Summary
1. In order to test our hypothesis for the origin and transfer of Sf, a selffertile gene, as well as for the genetic constitution of several almond cultivars, some preliminary protein analysis on pistils and pollen grains was carried out by isoelectric-focusing and SDS-PAGE in combination with a silver-nitrate staining procedure recently established. Some specific protein bands peculiar to Amygdalus webbii and 'Tuono' were observed. This could indicate the transfer of the Sf gene from the former to the latter. Some specific protein bands on certain cultivars and strains also appeared. These may be related to $\mathrm{S}_{2}, \mathrm{~S}_{3}$ or $\mathrm{S}_{4}$. We believe that our hypothesis could be proved through further electrophoretic analysis.

2. Artificial pollination was carried out among the 4 cultivars and strains whose genetic constitution is supposed to be $\mathrm{S}_{1} \mathrm{~S}_{3}$, and the pollen behavior in pistils soon after pollination was investigated by means of fluorescent microscopy. Two remarkable features were observed: namely, bad adhesion of pollen grains stigma surfaces and abnormal tube thinning with poor callose accumulation onto tube walls. This revealed the existence of cross-incompatibility among No.484, 'Ferraduel', 'Ferralise' and No.892. It seems that stigmas are very critical in pollination incompatibility of almonds.
\end{abstract}

\section{Introduction}

Self-compatibilty is one of the most important characteristics to be introduced into almond cultivars. It could be controlled by what we call $\mathrm{S}$ genes. Based upon our crossing experiments so $f a r(6,7)$, we have developed a hypothesis on the genetic constitution of some almond cultivars and their wild relative Amygdalus webbii (Fig. $1 ; 10$ ). In this hypothesis, it is supposed that Sf, a self-fertile gene, originates in A.webbii and is transferred to some almond cultivars like 'Tuono' and 'Fillip Ceo' through open polli-

1 Received for publication July 29, 1986. nation in southern Italy. In order to test this hypothesis, some preliminary protein analysis of pistils and pollens of these materials was performed by isoelectric-focusing and SDS-PAGE, using a silver-nitrate staining procedure recently established. In addition, some microscopic observations were carried out to confirm the presence of cross-incompatibility among several cultivars and strains whose genetic constitutions are thought to be $\mathrm{S}_{1} \mathrm{~S}_{3}$.

\section{Materials and Methods}

1. Protein analysis by electrophoresis

In addition to A. webbii, the following cul- 


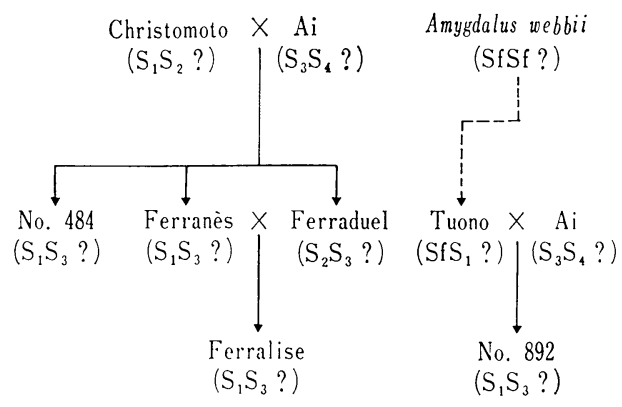

Fig. 1. A hypothesis on the genetic constitution of some almond cultivars and their wild relative Amydalus webbii

tivars and strains were used as experimental materials.

1. 'Ai', 2. 'Christomoto', 3. 'Tuono', 4. No. 484 (a strain), 5. 'Ferraduel', 6. 'Ferragnés', 7. 'Ferralise', 8. No. 892 (a strain)

At flowering time in 1985 , pistils (including calyx) and pollen (unsieved) of these materials were collected from trees in the experimental orchard of I. N.R.A., Station de Recherches Fruitières Mèditerranèenes in Montfavet, France. They were packed into small plastic tubes and stored in liquid nitrogen in a metalic container until required for analysis.

Sample preparation was carried out in a cold room at $4^{\circ} \mathrm{C}$. The plant material wasr emoved from the liquid nitrogen and homogenized for 2 minutes in a bowl with

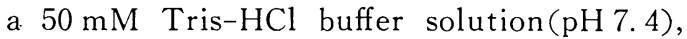
including E. D. T. A. (Ethylenediamine tetra acetic acid, $5 \mathrm{mM}), \quad$ D.T.T. (1, 4-Dithiothreitol, $1 \mathrm{mM}$ ) and P.V.P.P. (Polyvinylpolypyrolidone, $2 \%$ ). The homogenate was centrifuged in a Sigma $2 \mathrm{MK}$ centrifuge for 20 minutes at $5^{\circ} \mathrm{C}$ at a speed of $14000 \mathrm{rpm}$. The supernatant was distributed into small plastic tubes, which were all stored in a deep freezer at $-20^{\circ} \mathrm{C}$. This crude extract was run on isoelectric-focusing according to the routine procedure established by LKB Co. For SDS-PAGE, the method developed by Laemmli was employed(11). The crude extract was refined through the acetone precipitation procedure, and the final precipitate was dissolved by a Tris-glycerin solution, made by mixing $9 \mathrm{ml}$ of $62.5 \mathrm{mM}$ Tris- $\mathrm{HCl}$ buffer solution ( $\mathrm{pH} 6.8), 1 \mathrm{ml}$ of glycerin,

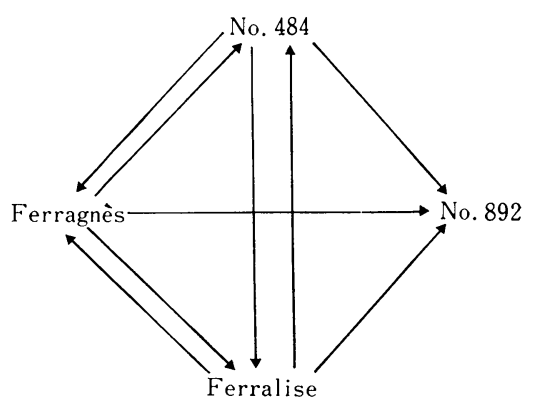

Fig. 2. Scheme of the artificial pollnation among the 4 cultivars and strains of almond $(\longrightarrow$ means the direction in which pollination was carried out)

$0.23 \mathrm{~g}$ SDS (Sodium dodecyl sulphate) and $0.2 \mathrm{~g}$ D. T. T. Then, it was boiled at $100^{\circ} \mathrm{C}$ for 5 minutes, and run on SDS-PAGE. The proteins distributed on the gel film by isoelectric-focusing and SDS-PAGE were stained with the silver nitrate staining procedure established by Morrisey(14).

2. Microscopic observation of pollen behavior

Flowers one day before anthesis were collected from the tress of strains No. 484, 'Ferragnes', 'Ferralise', and No. 892. Preparation of the flowers used for the indoor pollination was carried out based on the system of Jefferies et al(9). Petals and stamens were cut off with a razor blade. These detached, emasculated, and depetalled flowers were then put into a chamber at $20^{\circ} \mathrm{C}$ with their stalks soaked in tap water. After one hour, they were pollinated with pollen that had been collected in advance and stored several days at $4^{\circ} \mathrm{C}$ in a refrigerator. The pollination was accurately performed with brushes according to the scheme shown in Fig. 2. Six hours after pollination, the pistils were put into an F.A.A. solution to be fixed and stored. These pistils were twice rinsed with distilled water, transferred into a $5 \%$ Sodium sulphate solution and autoclaved for 30 minutes(8). The softened pistils were soaked in decolourized aniline blue solution for 10 minutes $(3,12)$. Then, the pistils were squashed and observed under a Reichert 'Zetopan' microscope using transmitted fluorescent light. 


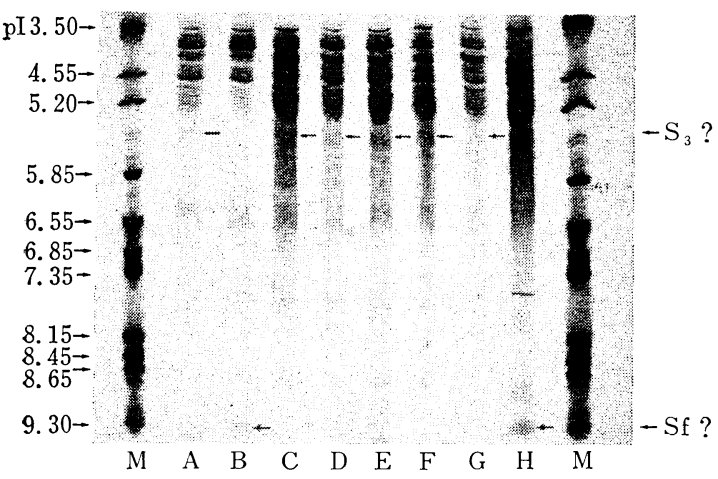

Fig. 3. Distribution of pistil proteins after isoelectric focusing A. Ai, B. Tuono, C. No.484, D. Ferraduel, E. Ferragnès, F. Ferralies, G. No.892, H. Amygdalus webbii, M. Protein marker

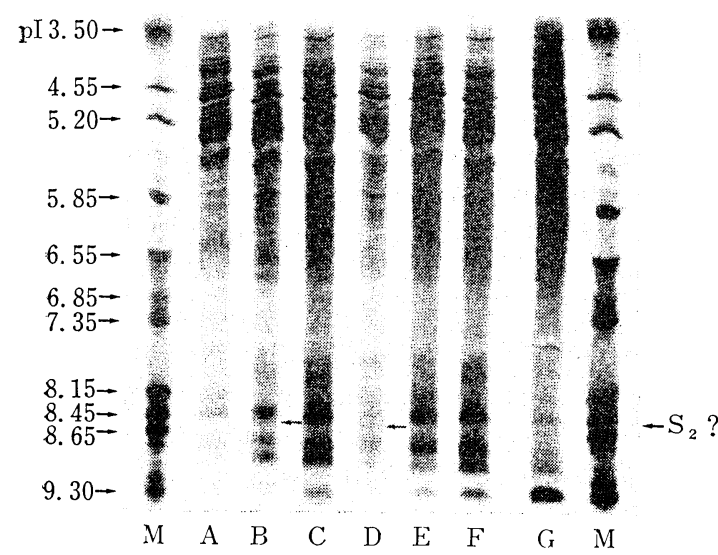

Fig. 4. Distribution of pollen proteins after by isoelectricfocusing A. Ai, B. Christomoto, C. Tuono, D. Ferraduel, E. Ferragnès, F. No. 892, G. Amygdalus webbii, M. Protein marker

\section{Results and Discussion}

1. Protein analysis by electrophoresis

Fig. 3 shows the distribution of pistil proteins under isoelectricfocusing. In the most basic portion around pI 9.30, there are two bands unique to $A$. webbii and 'Tuono'. These proteins could be derived from the Sf gene. In the acidic portion around pI 5.50, there are two clear bands just like a double eyelid. They exist on 'Ai', No. 484, 'Ferraduel', 'Ferragnes', 'Ferralise', and No. 892 that may have the $S_{3}$ gene in common.

Fig. 4 shows the distribution of pollen proteins under isoselectric-focusing. In the basic portion around pI 8.50 of 'Christomoto' and 'Ferraduel', there is a band peculiar to

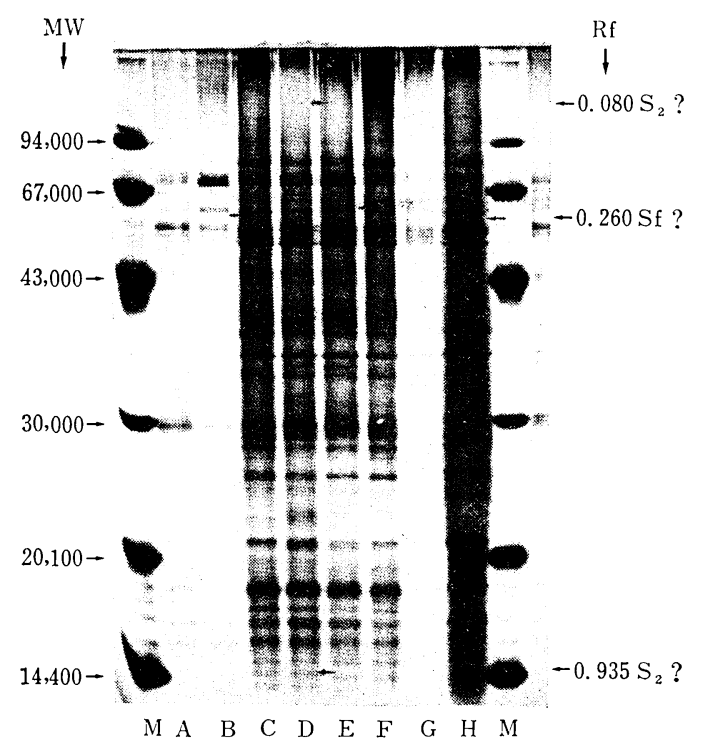

Fig. 5. Distribution of pistil proteins after SDSPAGE A. Ai, B. Tuono, C. No.484, D. Ferraduel, E. Ferragnès, F. Ferralise, G. No. 892, H. Amygdalus webbii, M. Protein marker

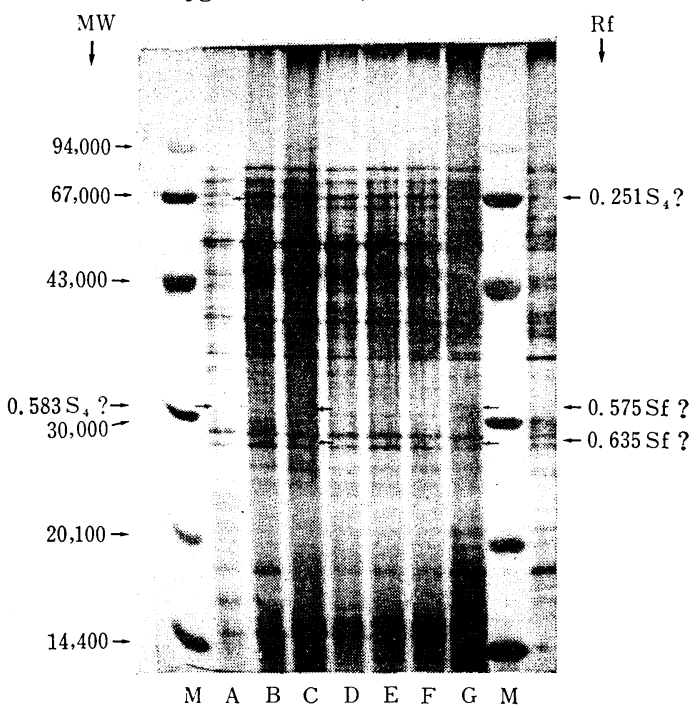

Fig. 6. Distribution of pollen proteins after SDSPAGE A. Ai, B. Christomoto C. Tuono, D. Ferraduel, E. Ferragnès, F. No. 862, G. Amydalus webbii, M. Protein maker

these two cultivars. The genetic constitutions of 'Christomoto' and 'Ferraduel' are supposed to be $\mathrm{S}_{1} \mathrm{~S}_{2}$ and $\mathrm{S}_{2} \mathrm{~S}_{3}$, respectively; therefore, this band could be related to the $\mathrm{S}_{2}$ gene.

Fig. 5 shows the distribution of pistil proteins under SDS-PAGE. There is a specific 


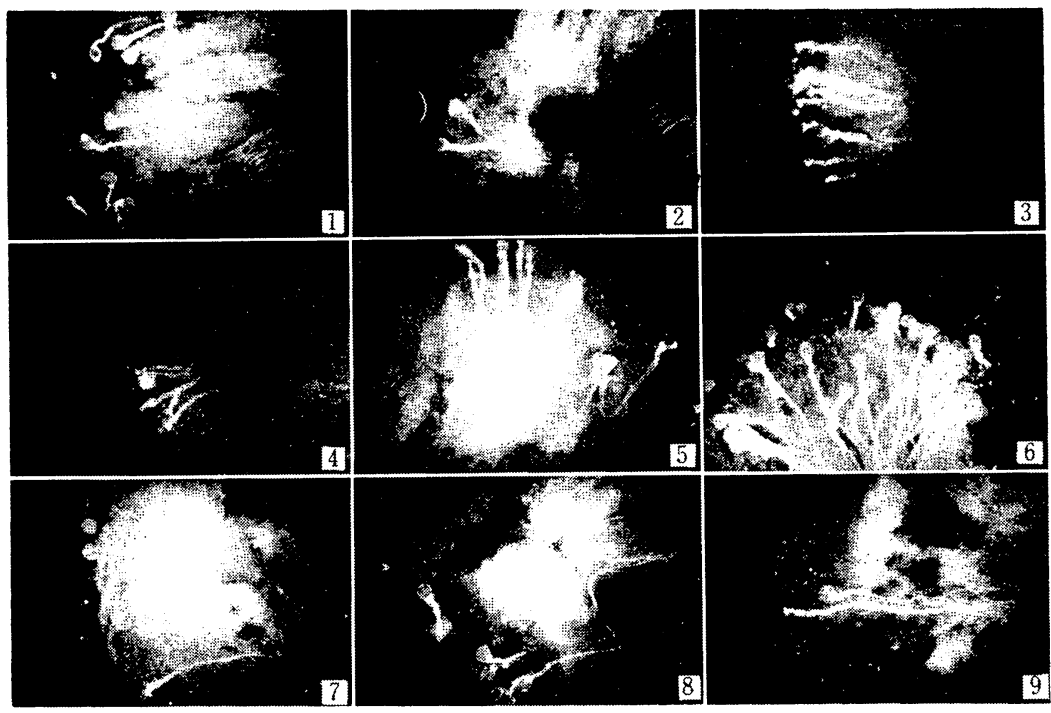

Fig. 7. Pollen germination in stigmas at 6 hours after cross-pollination among the 4 cultivars and stigmas of almond

1. No. $484 \times$ Ferragnès 2. Ferragnes $\times$ No. 484 3. No. $484 \times$ Ferralise 4. Ferralise $\times$

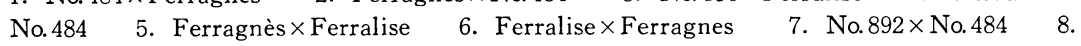
No. $892 \times$ Ferragnès 9 , No. $892 \times$ Ferralise

band at Rf 0.260 common to A.webbii and 'Tuono', which may be related to the Sf gene. There exist 2 specific bands on 'Ferraduel' at $\mathrm{Rf} 0.080$ and 0.935 , which may be related to the $\mathrm{S}_{2}$ Gene.

Fig. 6 shows the distribution of pollen proteins under SDS-PAGE. Two unique bands exist at $\operatorname{Rf} 0.575$ and 0.635 common to $A$. webbii and 'Tuono', which may be related to the Sf gene. At Rf 0.251 and 0.583, a unique band exists on 'Ai', which may be related to the Sf gene.

Judging from the results obtained here, our hypothesis mentioned in the introduction seems to be strengthened. Generally, Prunus species are considered to show gametophytic incompatibility, where any incompatible pollen tubes are arrested in styles following tube top enlargement or bursting. This phenomenon could be an antigen-antibody reaction between pollen tubes and transmitting tissues of the style, where some specific glycoproteins might be involved. In fact, the recent data published by Raff et al(16) and Mau et al(13) have clarified the unique presence of specific glycoproteins in the styles of Prunus avium which has a genetic consti- tution of $\mathrm{S}_{3} \mathrm{~S}_{4}$. In the present experiment, the whole pistil including calyx was homogenized for the protein analysis. In order to increase the efficiency of the protein analysis, it is essential to know what portion of the pistil could be most critical in the incompatible reactions of almonds.

\section{Microscopic observation}

Fig. 7 shows the pollen germination in stigmas 6 hours after cross-pollination that was carried out among the 4 cultivars in question. All the pictures show that there were very few pollen grains germinated on stigmas. This could have been caused by bad adhesion of pollen grains which could be related to the incompatible reactions. In fact, Yamashita (1984, unpublished) has observed this kind of bad adhesion of pollen grains in self-pollination of 'Kosui', a self-incompatibel Japanese pear cultivar. Moreover, any pollen tubes that could penetrate into stigmas became thinner and thinner with a minimized accumulation of callose on their tube walls, and finally their tube tips became difficult to see. This might mean that pollen tubes could not get enough energy from pistils, probably due to some important reactions. 
This kind of discussion may contradict the general conception, e.g. Ascher's gene action model(1), but recent reports have indicated the significance of the reactions in stigmas in some gametophytic incompatible plants (4, $15,17,18,19,20,21)$. This phenomenon described here, however, was not observed after compatible pollinations of almonds already reported $(2,5,15)$. Therefore, we could conclude that pollination incompatibility certainly exists among No.484, 'Ferragenes', 'Eerralise' and No. 892. These cultivars and strains could have the same genetic constitution, supposed to be $\mathrm{S}_{1} \mathrm{~S}_{3}$.

\section{Further discussion}

Judging from the results of protein analysis together with microscopic observation, several points must be considered in our further research.

(1) For the protein analysis, it would be better to focus on 'Tuono', 'Fillip Ceo' and some other self-compatible cultivars from southern Italy as compared with $A$. webbii. Pistils should be divided into several parts, i. e. stigma, style, and ovary, to be analyzed by electrophoresis, where more attention should be paid to the result with stigmas, because the microscopic observations of the present experiment showed that critical incompatible reactions are likely to occur soon after the pollen lands on the stigma surface. In this connection, protein analysis of pollen grains should not be neglected for the same reason. Their glycoprotein composition could be a decisive key in this comparison, since glycoproteins are known to be closely related to the $\mathrm{S}$ gene expression in Prunus.

(2) A backcross of 'Tuono' or 'Fillip Ceo' with A.webbii might be very instructive, because half the progenies are expected to be homozygous for the Sf gene. Homozygotes could be very useful in the protein analysis for the purpose of finding a specific band on the gel film.

\section{Literature Cited}

1. AsHer, P. D. 1966. A gene action model to explain gametophytic self-incompatibility. Euphytica $15: 179-183$.

2. CRISTEN, N. 1985. Autocompatibilite chez
l'amandier-Evaluation des potentialités de croissance de l'autopollen chez des hybrides issus de 'Tuono'. Memoire de fin d'etudes E. N. S. A. Monpellier : 1-42.

3. CURRIER, H. B. 1957. Callose substances in plant cells. Amer. J. Bot. 44:478-482.

4. DoNK, J. A. W. M. 1974. Gene activity and incompatibility reaction in Petunia, p. 279283. In : H. F. Linskens (ed). Fertilization in higher plants.

5. GoDINI, A. 1981. Observing pollen tube growth in self-compatible almond cultivars by means of fluorescence. Options 1981: 77 -82 .

6. Grasselly Ch. and G. Olivier. 1976. Mise en évidence de quelques types autocompatibles parmi les cultivars d'amandier (Prunus amygdalus Batch) de la population des Poilles. Ann. Amelior. Pl. 26:107-113.

7. Grasselly Ch. and P. Crossa-Raynaud, G. OLIVIER and H. GALL. 1981. Transmission du caractère d'autocompatibilite chez l'amandier (Amygdalus communis). Options 1981: $71-75$.

8. JefFeries, C. J. and A. R. BelCher. 1974. A fluorescent brightener used for pollen tube identification in vivo. Stain Tech. 49:199202.

9. Jefferies, C. J., P. Brain, K. G. Stott and A. R. BELCHER. 1982. Experimental systems and a mathematical model for studying temperature effects on pollen tube growth and fertilization in plum. Plant, Cell and Environment $5: 231-236$.

10. JOUJiER, M. 1984. Etude de la transmission du caractère d'autocompatibilite chez l'espece A mandier. Memoire de fin d'detudes I. S. A. B. Beuvais : $1-50$.

11. LAemmLI, J. K. 1970. Cleavage of structural proteins during the assembly of the head of bacteriophage T4. Nature $227: 680-685$.

12. Martin, F. W. 1959. Staining and observing pollen tubes in the style by means of fluorescence. Stain Tech. 34:125-128.

13. MaU, S. L., J. W. RafF and A. E. Clarke. 1982. Isolation and partial characterization of components of Prunus avium L.styles, including an antigenic-glycoprotein associated with a self-incompatibility genotype. Planta $156: 505-516$.

14. MorRisey, J. H. 1981. Silver stain for proteins in polyacrylamide gels; A modified procedure with enhanced uniform sensitivity. Anal. Biochem. $117: 307-310$.

15. Pimienta, E., V.S. Polito and D. E. Kester. 
1983. Pollen tube growth in cross- and selfpollinated 'Nonpareil' almond. Amer. Soc. Hort. Sci. 108 : 643-647.

16. RAFF, J. W., R. B. KNOX and A. E. Clarke. 1981. Style antigens of Prunus avium L. Planta $153: 125-129$.

17. YAmAShita, K. 1978. Studies on self-incompatibility of Hyuganatsu, Citrus tamurana Hort. ex Tanaka. 1. Pollen behavior on stigmas and pollen tube growth in styles observed under a scanning electron microscope. J. Japan. Soc. Hort. Sci. 47 : 188-194.

18. YAMASHITA, K. 1980. Studies on self-incompatibility of Hassaku (Citrus hassaku Hort. ex Tanaka) 1. On the pollen behavior in pistils in self-pollination, and the effect of various treatments to overcome the self-incompatibility. J. Japan. Soc. Hort. Sci. $49: 49-56$.
19. YAmAshita, K. 1981. Studies on self-incompatibility of Hyuganatsus (Citrus tamurana Hort. ex Tanaka) 2. On the sequential changes of protein composition in selfpollinated pistils, and the effect of various treatments to overcome the self-incompatibility. J. Japan. Soc. Hort. Sci. 49 : 497504.

20. YAmAShitA, K. 1981. Stigma exudate application for overcoming self-incompatibility of Hyuganatsu and Hassaku. Proc. Int1. Citriculture 1981 : 48-51.

21. Yamashita, K. and S. TAnimoto. 1985. Studies on self-incompatibility of Hassaku ( $\mathrm{C} i$ trus hassaku Hort. ex Tanaka)-Glycoprotein composition in pistils soon after selfpollination, and the effects of treatments to. overcome self-incompatibility. J. Japan. Soc. Hort. Sci. $54:$ 178-183.

\title{
アーモンドの雌ずいならびに花粉のタンパク分析—とくに 自家和合性遺伝子 Sf との関連について
}

\author{
山下研介 \\ 宮崎大学農学部 889-21 宮崎市 \\ T. Gaude and C. Dumas \\ クラウド・ベルナルド・リヨン第 1 大学, リヨン, フランス
}

Ch. Grasselly and P. Crossa-Raynaud

I. N. R.A. 果樹試験場，モンフアベ，フランス

\begin{abstract}
摘 要
1. アーモンドの自家和合性遺伝子 Sf の起原と伝播 ならびにアーモンド数品種の $\mathrm{S}$ 遺伝子組成に関する我々 の仮説を実証することを目的として，新しく開発された 銀染色法を用いた等電点電気泳動法ならびに SDSPAGE 法によって，雌ずいならびに花粉のタンパクを 分析した。 その結果, Amygdalus webbii と 'Tuono' に共通のいくつかのタンパクバンドが存在し, 前者から 後者へSf 遺伝子が伝えられた可能性が示唆された. 又, その他の品種, 系統についての分析結果より, $\mathrm{S}_{2}, \mathrm{~S}_{3}, \mathrm{~S}_{4}$ に関与すると思われるいくつかのタンパクバンドも認め られ，今後さらに検討を加えることによって，仮説の妥

当性が実証されるものと思われた～

2. S 遺伝子組成がいずれも $\mathrm{S}_{1} \mathrm{~S}_{3}$ と思われるアーモ ンド 4 品種（系統）間で人工受粉を行い, 雌ずい内の花 粉管伸長を蛍光顕微鏡で観察した．その結果，これらの 交配組み合わせでは, 柱頭への花粉の付着は不良で, 花 粉管伸長に際してカロースの管壁への蓄積がきわめて不 良であった。このことより，484 系統，'Ferraduel', 'Ferralise’ならびに 892 系統間には, 交配不和合性が 存在するもと思われた・アーモンドの不和合反応におい ては, 柱頭がきわめて重要な役割を果しているものと思 われる。
\end{abstract}

